\title{
Effect of lactation number, year, and season of initiation of lactation on milk yield of cows hormonally induced into lactation and treated with recombinant bovine somatotropin
}

\author{
M. Mellado, ${ }^{\star 1}$ E. Antonio-Chirino,† C. Meza-Herrera,‡ F. G. Veliz,† J. R. Arevalo,§ J. Mellado, ${ }^{\star}$ \\ and A. de Santiagot \\ *Department of Animal Nutrition, Autonomous Agrarian University Antonio Narro, 25315 Saltillo, Mexico \\ †Faculty of Veterinary Medicine, Autonomous Agrarian University Antonio Narro, 27010 Torreon, Mexico \\ łUniversidad Autónoma Chapingo, Unidad Regional Universitaria de Zonas Aridas, 35230 Bermejillo, Mexico \\ §Department of Parasitology, Ecology and Genetics, University of La Laguna, 38200 La Laguna, Spain
}

\begin{abstract}
Records representing data from 1,500 barren Holstein cows over an 8-yr period from a large commercial dairy farm in northern Mexico were analyzed to determine the effects of lactation number and season and year of initiation of lactation on milk production of cows induced hormonally into lactation and treated with recombinant bovine somatotropin (rbST) throughout lactation. Peak and 305-d milk yields were also assessed as predictors of total milk yield in cows induced into lactation. A significant quadratic relationship was found between 305-d milk yield and number of lactation $[7,607 \pm 145$ and $9,548 \pm 181 \mathrm{~kg}$ for first- and $\geq 6$-lactation cows, respectively; mean \pm standard error of the mean (SEM)] with the highest production occurring in the fifth lactation. Total milk yields of cows with $\leq 2$ lactations were approximately $4,500 \mathrm{~kg}$ less than milk yields of adult cows (the overall average \pm standard milk yield was $13,544 \pm 5,491 \mathrm{~kg}$ per lactation and the average lactation length was $454 \pm 154 \mathrm{~d}$ ). Moreover, 305-d milk production was depressed in cows induced into lactation in spring $(8,804 \pm 153 \mathrm{~kg}$; mean \pm SEM) and summer $(8,724 \pm 163 \mathrm{~kg})$ than in fall $(9,079 \pm 151 \mathrm{~kg})$ and winter $(9,085 \pm 143 \mathrm{~kg})$. Partial regression coefficients for 305-d milk yield and peak milk yield indicated an increment of $157 \mathrm{~kg}$ of milk per lactation per 1-kg increase in peak milk yield $\left(\mathrm{r}^{2}\right.$ $=0.69)$. Neither peak milk yield $\left(\mathrm{r}^{2}=0.18\right)$ nor $305-\mathrm{d}$ milk yield $\left(\mathrm{r}^{2}=0.29\right)$ was accurate for predicting total milk yield per lactation. Year, parity, and season effects had significant influence on milk yield of cows induced into lactation and treated with rbST throughout lactation, and peak milk yield can assist in the prediction of 305-d milk yield but not total milk yield. This study also showed that hormonal induction of lactation in
\end{abstract}

Received January 5, 2011.

Accepted May 11, 2011.

${ }^{1}$ Corresponding author: mmellbosq@yahoo.com barren high-yielding cows is a reliable, practical, and affordable technique in countries where rbST treatment and prolonged steroid administration of dairy cows are legally permitted.

Key words: lactation induction, somatotropin, extended lactation, predicted milk yield

\section{INTRODUCTION}

The major milk-producing region of Mexico is in a hot, arid environment in the northeastern part of the country. In this agroecological area, extended periods of high ambient temperature and intense solar radiation are one of the leading causes of a drastic reduction in fertility of large high-yielding dairy herds operating in this area (Sepulveda, 2009); hence, low breeding efficiency is a generalized herd problem among milk producers in this arid environment. This failure to breed results in long calving intervals and substantial nonvoluntary culling losses, which leads to decreases in profit from lost milk sales and increased costs of reproduction (Arbel et al., 2001; St. Pierre et al., 2003).

Culling rates in these dairy operations are well over $35 \%$ per year (Avendaño Reyes et al., 2007), and many of these cows are culled prematurely due to reproductive failure, leading to a higher number of heifers required. Because these dairy operations depend greatly on significant heifer importation from United States and Canada, the cost of maintaining the herd (i.e., the cost of rearing and importing replacements less the value of culled cows sold) constitutes a major percentage of the dairy herd variable costs.

To reduce herd culling losses and replacement costs, a widespread strategy adopted by farm businesses in this zone is the hormonal induction of lactation in cows unable to become pregnant, coupled with prolonged lactations $(>400 \mathrm{~d})$ via the administration of rbST throughout lactation.

This now practical and reliable procedure (Mellado et al., 2006) has a significant effect on costs because it 
allows farmers to reduce herd culling losses and replacement costs by retaining outstanding cows that would otherwise be culled from the dairy herd. Additionally, this management practice allows prolonged lactations $(>450 \mathrm{~d})$ and an increment in herd biosecurity, as fewer replacements are introduced into the herd.

Because this technology is now used as an integrated milk production management program in many dairy operations in Mexico, information on factors affecting the lactation response of cows hormonally induced into lactation is required. The purpose of this study, therefore, was to analyze the factors that affect milk production and lactation length of Holstein cows induced into lactation and treated with rbST throughout lactations. An additional objective was to assess the feasibility of using peak milk yield as a predictor of 305-d and fulllactation milk yield of cows hormonally induced into lactation.

\section{MATERIALS AND METHODS}

\section{Study Herd and On-Farm Data Collection}

The experimental procedures and animal care conditions were approved by the Ethics Committee of the Research Department of the Agrarian Autonomous University Antonio Narro. The study was carried out in a large dairy herd located in northeastern Mexico $\left(26^{\circ} 23^{\prime} \mathrm{N}, 104^{\circ} 47^{\prime} \mathrm{W}\right.$, elevation $1,140 \mathrm{~m}$, mean annual temperature $27^{\circ} \mathrm{C}$, mean annual rainfall $230 \mathrm{~mm}$ ) from 2005 to 2009. The herd consisted of Holstein cows housed in open, dirt pens. All pens were equipped with evaporative coolers, which injected a fine mist of water into turbulent air from electric fans installed on shade roofs. Shades were equipped with curtains that descended automatically when ambient temperatures reached $28^{\circ} \mathrm{C}$.

Prepartum diets were fed from 3 wk before expected parturition until calving, and then all cows were fed diets formulated to provide recommended total daily nutrients for a $670-\mathrm{kg}$ dairy cow producing $>33 \mathrm{~kg}$ of milk/d (NRC, 2001). Cows were fed diets that contained a 45:55 forage to grain ratio (DM basis) for the entire lactation. Diets contained ground shelled corn and soybean meal as the base ingredients of the concentrate mix; the forage portion of the diet was $50 \%$ alfalfa hay and $50 \%$ corn silage (DM basis). Cows were fed ad libitum (10\% remnants of food) 4 times daily at 0600 , 1000, 1200, and $1600 \mathrm{~h}$. Lactating cows were allocated to 3 lactation-stage groups $(70 \pm 13,145 \pm 12$, and $\geq 210 \pm 9 \mathrm{~d}$ in milk).

Cows were milked 3 times daily $(0600,1400$, and 2100 h) throughout the study in milking parlors. All cows were subjected to rbST administration (subcutaneous) every $14 \mathrm{~d}$ beginning at 60 DIM and continuing until 2 wk before drying off. Milk weights were recorded daily electronically and this information was transferred to a dairy records database. Information on date of initiation of lactation, end of lactation, and lactation number was recorded. Cows with prolonged lactations $(>600$ d) were allowed to continue milking for economical reasons and were dried off when the daily milk yield was $<15 \mathrm{~kg}$, regardless of parity or season; therefore, every cow in the present population was given an equal opportunity to have an extended lactation.

\section{Induction of Lactation}

In total, 1,500 complete lactations records of Holstein cows induced into lactation between 2002 and 2009 were used in the analysis. Cows were selected for induced lactation if they did not become pregnant after 6 services if nulliparous, or 7 services in pluriparous cows. All cows had previously been hormonally induced for timed breeding.

Infertile cows (determined nonpregnant by rectal palpation) from 1 to 6 previous lactations and with a dry period $\geq 50 \mathrm{~d}$ were induced into lactation by administering daily s.c. injections of estradiol cypionate at $2 \mathrm{mg} / \mathrm{kg}$ of BW per day (Pfizer, Mexico DF, Mexico; esterified estrogen more potent and longer lasting than estradiol-17 3 ) and $0.10 \mathrm{mg} / \mathrm{kg}$ of BW per day progesterone (Pfizer) from d 1 to 7 . Estradiol cypionate (2 $\mathrm{mg} / \mathrm{kg}$ ) was applied from d 8 to 14 . Somatotropin (Lactotropin, $500 \mathrm{mg}$ of zinc bST, Elanco Animal Health, Guadalajara, Mexico) was applied on d 1, 6, 16, and 21. Lactation was triggered by administration of 0.03 $\mathrm{mg} / \mathrm{kg}$ of BW per day of flumethasone (Fluvet, Fort Dodge, México DF, Mexico) injected s.c. daily for $3 \mathrm{~d}$ (d 18 to 20). Milking was initiated on d 21. All cows were destined to be culled after the induced lactation; therefore, they were not inseminated while lactating.

\section{Statistical Analysis}

Data were initially edited to eliminate cows with incomplete lactations (due to disease or culling of animals), with a previous lactation induced hormonally, or with dry periods $<40 \mathrm{~d}$, or cows that accidently became pregnant during the induced lactation. In addition, the UNIVARIATE procedure of SAS 9.1 (SAS Institute, Cary, NC) was used to determine outlier cows. Records that were $>2.5$ standard deviations from the mean for 305-d milk yield were considered outliers and were excluded from the analyses. This editing procedure resulted in 1,500 records for analysis.

Data for 305-d milk yield, total milk yield (defined as the cumulative daily test milk weights for all days 
of lactation), daily milk yield (305-d milk yield divided by 305 ), lactation length, milk production at the peak of lactation curve, and days at peak of lactation (all dependent variables) were analyzed using the MIXED procedure of SAS (version 9.1). The model included fixed effects of lactation number (4 classes: 1-2, 2-4, $4-6,>6$ ), season of initiation of lactation (4 seasons of the year), year of the beginning of lactation (8 years), and the interaction between lactation number and season of the beginning of lactation. Seasons were fall (August-October), winter (November-January), spring (February-April), and summer (May-July). For the analysis of the effect of season on milk production traits, lactation number was included as covariate in the model.

Treatment means were separated using the probability of a statistical difference (PDIFF option of SAS). Statistical differences were considered significant at $P$ $\leq 0.05$ and data are presented as least squares means \pm SEM. Regression analyses were applied to discern any relationship between peak milk yield and 305-d milk production or total milk production per lactation. A regression analysis was also used to assess the association between 305-d milk yield and total milk yield. A polynomial regression analysis was used to describe the relationship between lactation number and 305-d milk yield.

\section{RESULTS AND DISCUSSION}

Multiple studies on the effect of lactation number on milk yields of cows whose lactations derive from gestation and parturition have been conducted (Ray et al., 1992; Arbel et al., 2001; Çilek, 2009). Essentially all studies have demonstrated that milk production increases with lactation number and is maximized in the fourth or fifth lactation. This is a result of the increasing development and size of the udder (Davis and Hughson, 1988) with a consequent increase in number of secretory cells (Sorensen et al., 2006). Other reasons for increased milk yield with increased parity are differences in the control of tissue mobilization between primiparous and multiparous cows (Wathes et al., 2007), different endocrine background at parturition in the less mature cows, which limits partitioning of nutrients into milk (Wathes et al., 2007), lower consumption of feed per day of primiparous cows than multiparous cows (Dado and Allen, 1994), and the increasing body size of older cows over that of first-lactation animals. Similar results were found in the present study, where 305 -d milk yield of cows with 2 lactations was $17 \%$ greater $(P<0.01$; Figure 1$)$ than that of first-lactation cows, and third-lactation cows produced $5.5 \%$ more milk than second-lactation cows. The greatest 305-d

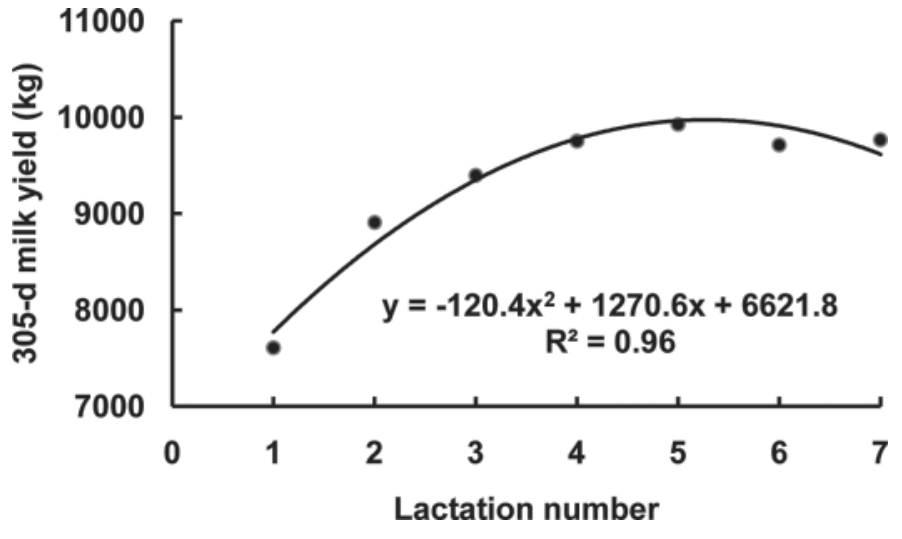

Figure 1. The relationship between 305-d milk yield of Holstein cows hormonally induced into lactation and lactation number.

milk yield occurred in the fifth lactation $(9,561 \pm 147$ $\mathrm{kg}$; mean \pm SEM), with a steady decline thereafter. Much lower 305-d milk yield in cows hormonally induced into lactation than that noted in the present study was reported by Magliaro et al. (2004). The lack of rbST in the induction protocol, fewer milkings per day, and much lower estradiol (25 times lower than the present study) in the Magliaro et al. (2004) study might explain this difference.

Data on total milk yield are presented in Table 1. Cows with more than 2 lactations had greater total milk yield $(P<0.01)$ than younger cows $(<2$ lactations). After 2 lactations, we did not find a tendency for total milk yield per lactation to decline as the number of lactations progressed. These data are not in agreement with other research in cows whose lactation derived from calving, where total milk production significantly increased but at a decreasing rate with lactation number (Ray et al., 1992). These data show that cows with $\geq 6$ lactations are still good candidates for hormonal induction of lactation, because milk yields of these animals were as high as those reached by younger cows.

The apparent contradiction between the decline in 305-d milk yield in cows with more than 5 lactations and no decline in total milk yield in old cows seems to stem from the fact that cows in the present study were deliberately managed for extended lactation, with emphasis in maximizing lactation persistency with sustained application of rbST. Additionally, dairy cows respond well to good nutrition even at 22 mo of lactation (Auldist et al., 2011), and mature cows seems to respond better to frequent milking than do primiparous cows (DePeters et al., 1985).

These records of total milk yield production are far above the values reported by Magliaro et al. (2004) for cows induced into lactation, but are similar to that re- 
Table 1. The effect of lactation number on complete lactation milk production, lactation length, daily milk yield, peak milk yield, and days of peak milk yield of rbST-treated Holstein cows hormonally induced into lactation and kept nonpregnant throughout lactation ${ }^{1}$

\begin{tabular}{|c|c|c|c|c|c|c|}
\hline $\begin{array}{l}\text { Lactation } \\
\text { number }\end{array}$ & $\mathrm{n}$ & $\begin{array}{l}\text { Total milk } \\
\text { yield (kg) }\end{array}$ & $\begin{array}{l}\text { Lactation } \\
\text { length (d) }\end{array}$ & $\begin{array}{l}\text { Daily milk } \\
\text { yield (kg) }\end{array}$ & $\begin{array}{c}\text { Peak milk } \\
\text { Yield }(\mathrm{kg} / \mathrm{d})\end{array}$ & $\begin{array}{c}\text { Day of peak } \\
\text { milk yield }\end{array}$ \\
\hline$<2$ & 328 & $10,071 \pm 281^{\mathrm{a}}$ & $414 \pm 9^{\underline{\mathrm{a}}}$ & $25.7 \pm 0.4^{\mathrm{a}}$ & $38.5 \pm 0.8^{\mathrm{a}}$ & $123 \pm 2.9^{\mathrm{a}}$ \\
\hline $2-4$ & 768 & $14,470 \pm 186^{\mathrm{b}}$ & $502 \pm 11^{\mathrm{bc}}$ & $28.3 \pm 0.3^{\mathrm{b}}$ & $41.7 \pm 0.7^{\mathrm{b}}$ & $106 \pm 2.5^{\mathrm{b}}$ \\
\hline $4-6$ & 339 & $14,588 \pm 281^{\mathrm{b}}$ & $479 \pm 9^{\mathrm{b}}$ & $28.4 \pm 0.4^{\mathrm{b}}$ & $41.0 \pm 0.8^{\mathrm{b}}$ & $113 \pm 2.9^{\mathrm{b}}$ \\
\hline$>6$ & 65 & $14,680 \pm 642^{\mathrm{b}}$ & $483 \pm 19^{\mathrm{bc}}$ & $27.6 \pm 0.8^{\mathrm{b}}$ & $40.3 \pm 1.3^{\mathrm{a}}$ & $106 \pm 5.0^{\mathrm{b}}$ \\
\hline
\end{tabular}

${ }^{\mathrm{a}-\mathrm{c}}$ Within columns, means with different superscripts are significantly different $(P<0.01)$.

${ }^{1}$ Values are least squares means \pm SEM.

corded by Mellado et al. (2006) in this zone and under the same management conditions. Thus, these results reaffirm that the lactation induction methodology is a practical and effective tool that allows high and persistent milk yields in reproductively incompetent cows, regardless of lactation number.

Considerable variation was observed in lactation length between young and pluriparous cows. Lactations of younger animals ( $<2$ lactations) were around $70 \mathrm{~d}$ shorter $(P<0.01)$ than those of cows with $>2$ lactations. In all cases, average lactations were more than $165 \mathrm{~d}$ longer than the traditional 305-d lactation in cows calving at intervals of 12 mo. High-yielding dairy cows are capable of lactations well beyond 400 d (Osterman and Bertilsson, 2003; Kolver et al., 2006; Auldist et al., 2009; Madsen et al., 2008;); however, dairy cows under intensive management lactate until milk secretion is drastically reduced by the advanced stage of gestation (Loker et al., 2009). Therefore, length of lactation is almost completely determined by length of calving interval.

In the present study, all cows were nonpregnant throughout lactation; thus, the depressing effect of gestation on milk production (Nørgaard et al., 2008) was absent, which allowed cows to express high milk persistency. Moreover, cows were milked thrice daily throughout lactation, which promotes high lactation persistency via mammary gland remodeling, the expression of paracrine factors, and modulation of hormone sensitivity (Flint and Knight, 1997; Bernier-Dodier et al., 2010). Furthermore, milk yield is maintained at a higher persistency with rbST supplementation compared with that without rbST (Chilliard et al., 1986; Chalupa and Galligan, 1989; Phipps et al., 1990; van Amburgh et al., 1997).

An additional advantage for milk producers adopting induction of lactation coupled with rbST administration in prolonged lactations would be higher carcass yield (many induced cows are destined for slaughter), because cows with long lactations end up with greater BW and BCS compared with cows undergoing 10-mo lactations (Auldist et al., 2007). This is because cows spend more time in positive energy balance after peak milk production (Kolver et al., 2006). Another economic advantage of these results would be the need for fewer replacement heifers to be raised.

The effect due to lactation number on peak milk production is presented in Table 1. No major trends were associated with second to sixth lactation, but both young and old cows had lower $(P<0.01)$ peak milk yield than middle-aged cows. As has been observed in previous studies (Mellado et al., 2006; Corradi Freitas et al., 2010), peak milk yield was attained much later in cows induced into lactation compared with cows not induced into lactation.

The delayed peak during induced lactation is not fully understood. It could be that induced cows have less secretory tissue at the beginning of lactation compared with noninduced cows, as mammary development occurs over a 20-d period in the former and during the last months of gestation in the latter (Knight and Wilde, 1993). Probably, the induced cows are less sensitive to the signaling pathways involved in downregulation of cell proliferation (Finucane et al., 2008) and present a longer postpartum period of secretory tissue proliferation, which would be reflected in delayed peak milk yield. Another possibility could be a greater degree of uncoupling and a delayed (or slower) recoupling of the somatotropic axis in the induced cows (Lucy et al., 2009), which could delay mammary development, which in turn would prolong maximum parenchyma volume, necessary for peak milk yield.

On the other hand, younger cows took longer $(P<$ 0.01 ) to attain peak milk yield than older cows. This response seems to be because young cows are not physically mature (Coffey et al., 2006); when they are approaching their first lactation they are in a different metabolic state compared with that of multiparous cows because they require nutrients for their own continued growth in addition to that of their udder development and milk synthesis (Wathes et al., 2007).

Season of calving affected milk traits significantly $(P<0.01$; Table 2$)$. Cows induced into lactation in the hotter seasons of the year (spring and summer) 


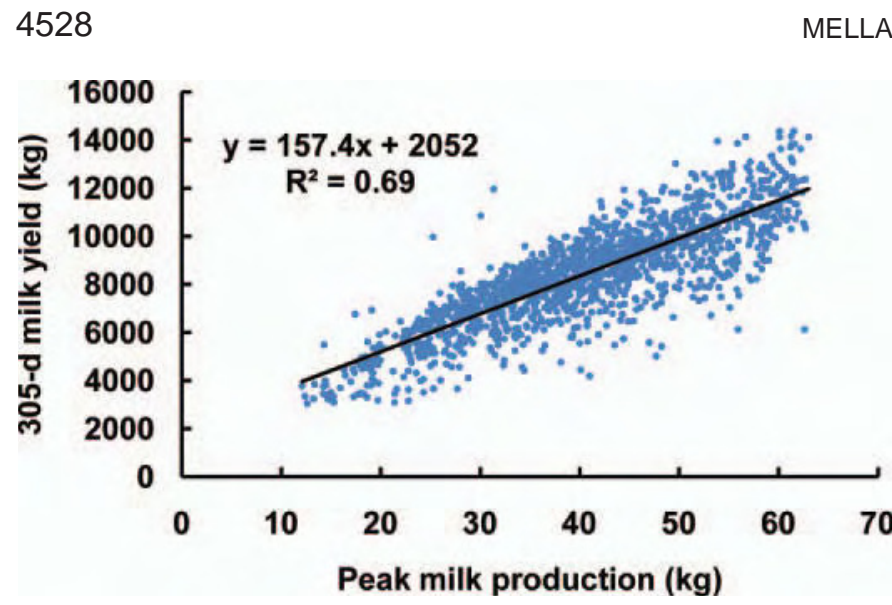

Figure 2. The relationship between peak milk production and 305d milk yield in barren Holstein cows hormonally induced into lactation and kept nonpregnant throughout lactation. Color version available in the online PDF.

showed the lowest $(P<0.01) 305-\mathrm{d}$ milk yield and those induced into lactation in the cooler seasons (fall and winter) showed the highest 305-d milk yield (Table $2)$. Regarding total milk yield and lactation length, cows initiating lactation in winter had the highest $(P$ $<0.01)$ milk yield compared with cows induced into lactation in all other seasons. Heat stress is one of the greatest challenges for milk yield in the arid zones of northern Mexico, because it compromises the ability of the lactating dairy cow to dissipate excess body heat (Berman et al., 1985; Igono et al., 1992). Dissipation of surplus body heat is exacerbated by the administration of rbST, which increases metabolic activity associated with greater milk yield (West, 1994).

Thermal stress is chronic in this area because intense radiant energy extends for a prolonged period (April to October). The effects of season detected in this study agree with earlier reports (Ray et al., 1992; Ravagnolo et al., 2000). The relationship of milk yield with season of calving is caused in part by seasonal variations in DMI (Holter et al., 1996, 1997; West et al., 2003) and lower efficiency in milk production due to the activation of the milk-borne negative feedback system (Silanikove et al., 2009).

Year of induction of lactation affected milk traits significantly $(P<0.01)$ : 305-d milk yield ranged from 8,268 to $9,485 \mathrm{~kg}$, whereas total milk yield ranged from 12,097 to $16,866 \mathrm{~kg}$. Commonly, when dairy herds are studied over several years, an increased milk production is observed. This response is due to a selection process (genetic change) and changes in handling and feeding conditions (environmental changes).

An early critical evaluation of milk production in cows induced into lactation once they reach the milking herd is important to determine the effectiveness of hormonal treatment. This can be done easily by monitoring peak milk because this variable was directly related to $305-\mathrm{d}$ milk yield (Figure 2). Each additional kilogram of milk production at peak translated into about $157 \mathrm{~kg}$ of additional milk in a standard 305-d lactation.

The regression analysis between peak milk yield and total milk yield described only a modest linear relationship (Figure 3). Our ability to predict total milk yield from peak milk yield was thwarted by the great variability in lactation length of cows (ranging from 301 to $1,388 \mathrm{~d}$ ). Likewise, the association between 305-d milk production and total milk yield was very weak (Figure 4) as a result of the great variability in persistency beyond $305 \mathrm{~d}$ in milk among cows. This was expected because cows with high persistency tend to produce less milk than expected at the beginning of lactation and more than expected at the end (Cole and VanRaden, 2006). High lactation persistency is associated with highly variable traits such as higher efficiency of feed utilization, higher resistance to disease, and reduced stress from high peak milk yield (Gengler, 1996; Appuhamy et al., 2009; Cole and Null, 2009). Additional factors affecting total milk yield are DMI and genetic merit of cows, but those factors were not included in the mixed models because of the difficulty in field data collection. Thus, these results suggest that peak milk yield alone is not a good predictor of milk yield beyond $305 \mathrm{~d}$ in nonpregnant cows induced into lactation.

Table 2. Milk yield, complete lactation milk production, lactation length, peak milk yield, and days of peak milk yield of rbST-treated Holstein cows hormonally induced into lactation and kept nonpregnant throughout lactation $^{1}$

\begin{tabular}{lcccccc}
\hline Season $^{2}$ & $\mathrm{n}$ & $\begin{array}{c}\text { 305-d milk } \\
\text { yield }(\mathrm{kg})\end{array}$ & $\begin{array}{c}\text { Total milk } \\
\text { yield }(\mathrm{kg})\end{array}$ & $\begin{array}{c}\text { Lactation } \\
\text { length }(\mathrm{d})\end{array}$ & $\begin{array}{c}\text { Peak milk } \\
\text { yield (kg/d) }\end{array}$ & $\begin{array}{c}\text { Day of peak } \\
\text { milk yield }\end{array}$ \\
\hline Winter & 551 & $9,085 \pm 143^{\mathrm{a}}$ & $14,563 \pm 384^{\mathrm{a}}$ & $492 \pm 11^{\mathrm{a}}$ & $41.5 \pm 0.7^{\mathrm{a}}$ & $105 \pm 2.7^{\mathrm{a}}$ \\
Spring & 333 & $8,804 \pm 153^{\mathrm{b}}$ & $13,414 \pm 436^{\mathrm{b}}$ & $457 \pm 12^{\mathrm{b}}$ & $39.0 \pm 0.8^{\mathrm{b}}$ & $108 \pm 3.1^{\mathrm{a}}$ \\
Summer & 296 & $8,724 \pm 163^{\mathrm{b}}$ & $13,439 \pm 454^{\mathrm{b}}$ & $465 \pm 13^{\mathrm{b}}$ & $39.3 \pm 0.9^{\mathrm{b}}$ & $120 \pm 3.2^{\mathrm{b}}$ \\
Fall & 320 & $9,079 \pm 151^{\mathrm{a}}$ & $13,706 \pm 430^{\mathrm{b}}$ & $464 \pm 12^{\mathrm{b}}$ & $41.6 \pm 0.8^{\mathrm{a}}$ & $115 \pm 3.1^{\mathrm{b}}$ \\
\hline
\end{tabular}

$\overline{\mathrm{a}, \mathrm{b}}$ Within columns, means with different superscripts are significantly different $(P<0.01)$.

${ }^{1}$ Values are least squares means \pm SEM.

${ }^{2}$ Winter $=$ November-January; spring $=$ February-April; summer = May-July; fall = August-October. 


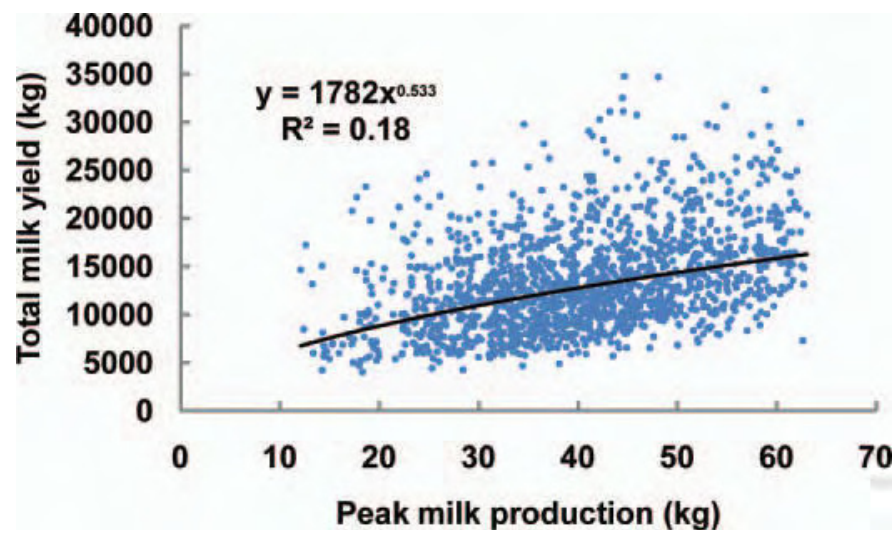

Figure 3. The relationship between peak milk yield and total milk yield in barren Holstein cows hormonally induced into lactation and kept nonpregnant throughout lactation. Color version available in the online PDF.

\section{CONCLUSIONS}

Findings show that 305-d milk yield increased with increasing number of lactations in high-yielding cows induced into lactation and subjected to long-term treatment with rbST, tapering off on the fifth lactation. After the second lactation, these barren cows deliberately managed for extended lactation, with emphasis in maximizing lactation persistency with sustained application of rbST, produced similar total milk yields, regardless of lactation number, indicating that old cows ( $>6$ lactations) are still suited for this management scheme. Because of the chronic heat load in this zone during most of the year, a mild negative effect of heat stress on 305-d milk yield was observed in cows induced into lactation in spring and summer. Peak milk yield proved to be a good predictor of 305-d

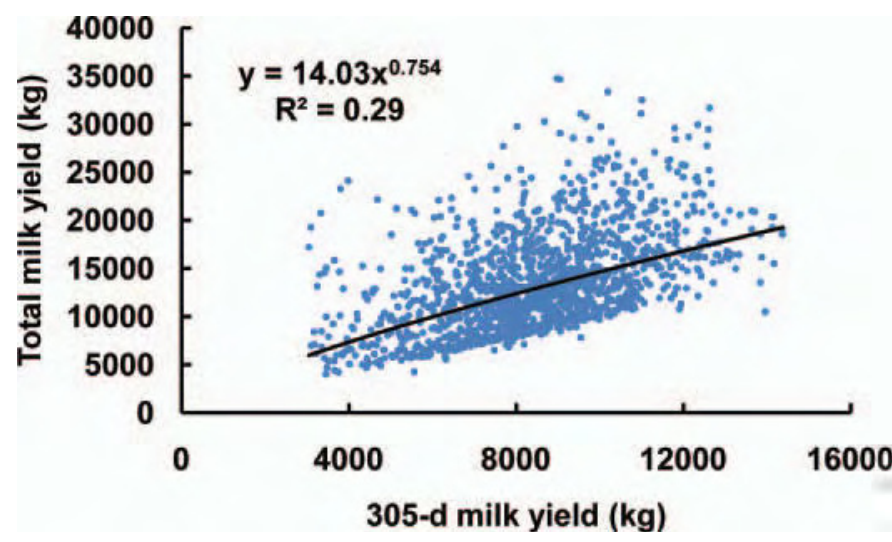

Figure 4. The relationship between 305-d milk yield and total milk yield in barren Holstein cows hormonally induced into lactation and kept nonpregnant throughout lactation. Color version available in the online PDF. milk yield but not total milk yield. The use of extended lactations in barren cows induced hormonally into lactations and treated with rbST throughout lactation in an intensive dairy farming system is commercially viable in countries where use of rbST and steroids is permitted in cattle. This system suits dairy producers in areas where a surplus of cull cows exists due to harsh ambient conditions, because it ameliorates poor reproductive performance in high-yielding dairy cows, as greater percentages of cows are lactating throughout the year, and fewer replacement heifers are required. This increase in farm efficiency is mainly due to extended herd life, additional milk income over feed costs, and reduced heifer costs per cow being replaced over a longer time.

\section{REFERENCES}

Appuhamy, J. A. D. R. N., B. G. Cassell, and J. B. Cole. 2009. Phenotypic and genetic relationships of common health disorders with milk and fat yield persistencies from producer-recorded health data and test-day yields. J. Dairy Sci. 92:1785-1795.

Avendaño Reyes, L., F. D. Álvarez Valenzuela, A. Correa Calderón, J. S. Saucedo Quintero, F. Rivera Acuña, F. J. Verdugo Zárate, C. F. Aréchiga Flores, and P. H. Robinson. 2007. Evaluation of a cooling system used in the dry period of dairy cattle in summer. Téc. Pecu. Méx. 45:209-225.

Arbel, R., Y. Bigun, E. Ezra, H. Sturman, and D. Hojman. 2001. The effect of extended calving intervals in high lactating cows on milk production and profitability. J. Dairy Sci. 84:600-608.

Auldist, M. J., C. Grainger, K. L. Macmillan, L. C. Marett, M. Hannah, B. J. Leury, and W. J. Wales. 2011. Feed conversion efficiency and marginal milk production responses of pasture-fed dairy cows offered supplementary grain during an extended lactation. Anim. Prod. Sci. 51:204-209.

Auldist, M. J., G. O'Brien, D. Cole, K. L. Macmillan, and C. Grainger. 2007. Effects of varying lactation length on milk production capacity of cows in pasture-based dairying systems. J. Dairy Sci. 90:3234-3241.

Berman, A., Y. Folman, M. Kaim, M. Mamen, A. Herz, D. Wolfenson, A. Arieli, and Y. Graber. 1985. Upper critical temperatures and forced ventilation effects for high-yielding dairy cows in a subtropical climate. J. Dairy Sci. 68:1488-1495.

Bernier-Dodier, P., L. Delbecchi, G. F. Wagner, B. G. Talbot, and P. Lacasse. 2010. Effect of milking frequency on lactation persistency and mammary gland remodeling in mid-lactation cows. J. Dairy Sci. $93: 555-564$.

Chalupa, W., and D. T. Galligan. 1989. Nutritional implications of somatotropin for lactating cows. J. Dairy Sci. 72:2510-2524.

Chilliard, Y., C. Delouis, M. C. Smith, D. Sauvant, and P. MorandFehr. 1986. Mammary metabolism in the goat during normal or hormonally-induced lactation. Reprod. Nutr. Dev. 26:607-615.

Çilek, S. 2009. Milk yield traits of Holstein cows raised at Polatli state farm in Turkey. J. Anim. Vet. Adv. 8:6-10.

Coffey, M. P., J. Hickey, and S. Brotherstone. 2006. Genetic aspects of growth of Holstein-Friesian dairy cows from birth to maturity. J. Dairy Sci. 89:322-329.

Cole, J. B., and D. J. Null. 2009. Genetic evaluation of lactation persistency for five breeds of dairy cattle. J. Dairy Sci. 92:2248-2258.

Cole, J. B., and P. M. VanRaden. 2006. Genetic evaluation and best prediction of lactation persistency. J. Dairy Sci. 89:2722-2728.

Corradi Freitas, P. R., S. G. Coelho, E. Rabelo, A. M. Quintao Lana, M. A. Torres Artunduaga, and H. Mattana Saturnino. 2010. Artificial induction of lactation in cattle. R. Bras. Zootec. 39:2268 2272 . 
Dado, R. G., and M. S. Allen. 1994. Variation in and relationships among feeding, chewing, and drinking variables for lactating dairy cows. J. Dairy Sci. 77:132-144.

Davis, S. R., and G. A. Hughson. 1988. Measurement of functional udder capacity in lactating Jersey cows. Aust. J. Agric. Res. 39:1163-1168.

DePeters, E. J., N. E. Smith, and J. Acedo-Rico. 1985. Three or two times daily milking of older cows and first lactation cows for entire lactations. J. Dairy Sci. 68:123-132.

Finucane, K. A., T. B. McFadden, J. P. Bond, J. J. Kennelly, and F. Q. Zhao. 2008. Onset of lactation in the bovine mammary gland: Gene expression profiling indicates a strong inhibition of gene expression in cell proliferation. Funct. Integr. Genomics 8:251-264.

Flint, D. J., and C. H. Knight. 1997. Interactions of prolactin and growth hormone $(\mathrm{GH})$ in the regulation of mammary gland function and epithelial cell survival. J. Mammary Gland Biol. Neoplasia 2:41-48.

Gengler, N. 1996. Persistency of lactation yields: A review. Proc. Int Workshop Genetic Improv. Funct. Traits Cattle, Gembloux, Belgium. Interbull Bull. 12:87-96.

Holter, J. B., J. W. West, and M. L. McGilliard. 1997. Predicting ad libitum dry matter intake and yield of Holstein cows. J. Dairy Sci. 80:2188-2199.

Holter, J. B., J. W. West, M. L. McGilliard, and A. N. Pell. 1996. Predicting ad libitum dry matter intake and yields of Jersey cows. J. Dairy Sci. 79:912-921.

Igono, M. O., G. Bjotvedt, and H. T. Sanford-Crane. 1992. Environmental profile and critical temperature effects on milk production of Holstein cows in desert climate. Int. J. Biometeorol. 36:77-87.

Knight, C. H., and C. J. Wilde. 1993. Mammary cell changes during pregnancy and lactation. Livest. Prod. Sci. 35:3-19.

Kolver, E. S., J. R. Roche, C. R. Burke, and P. W. Aspin. 2006. Effect of genotype and diet on milk solids production, body condition, and reproduction of cows milked continuously for 600 days. Proc. N.Z. Soc. Anim. Prod. 66:245-251

Loker, S., F. Miglior, J. Bohmanova, J. Jamrozik, and L. R. Schaeffer. 2009. Phenotypic analysis of pregnancy effect on milk, fat and protein yields of Canadian Ayrshire, Jersey, Brown Swiss, and Guernsey breeds. J. Dairy Sci. 92:1300-1312.

Lucy, M. C., G. A. Verkerk, B. E. Whyte, K. A. Macdonald, L. Burton, R. T. Cursons, J. R. Roche, and C. W. Holmes. 2009. Somatotropic axis components and nutrient partitioning in genetically diverse dairy cows managed under different feed allowances in a pasture system. J. Dairy Sci. 92:526-539.

Madsen, T. G., M. O. Nielsen, J. B. Andersen, and K. L. Ingvartsen. 2008. Continuous lactation in dairy cows: Effect on milk production and mammary nutrient supply and extraction. J. Dairy Sci. 91:1791-1801.

Magliaro, A. L., R. S. Kensinger, S. A. Ford, M. L. O'Connor, L. D Muller, and R. Graboski. 2004. Induced lactation in nonpregnant cows: Profitability and response to bovine somatotropin. J. Dairy Sci. 87:3290-3297.

Mellado, M., E. Nazarre, L. Olivares, F. Pastor, and A. Estrada. 2006. Milk production and reproductive performance of cows induced into lactation and treated with bovine somatotropin. Anim. Sci. 82:555-559.

NRC. 2001. Nutrient Requirements of Dairy Cattle. 7th rev. ed. Natl. Acad. Sci., Washington, DC.

Nørgaard, J. V., M. T. Sørensen, P. K. Theil, J. Sehested, and K. Sejrsen. 2008. Effect of pregnancy and feeding level on cell turnover and expression of related genes in the mammary tissue of lactating dairy cows. Animal 2:588-594.

Osterman, S., and J. Bertilsson. 2003. Extended calving interval in combination with milking two or three times per day: Effects on milk production and milk composition. Livest. Prod. Sci. 82:139 149.

Phipps, R. H., R. F. Weller, N. Craven, and C. J. Peel. 1990. Use of prolonged-release bovine somatotropin for milk production in British Friesian dairy cows. 1. Effect on intake, milk production and feed efficiency in two consecutive lactations of treatment. J. Agric. Sci. 115:95-104.

Ravagnolo, O., I. Misztal, and G. Hoogenboom. 2000. Genetic component of heat stress in dairy cattle, development of heat index function. J. Dairy Sci. 83:2120-2125.

Ray, D. E., T. J. Halbach, and D. V. Armstrong. 1992. Season and lactation number effects on milk production and reproduction of dairy cattle in Arizona. J. Dairy Sci. 75:2976-2983.

Sepulveda, E. 2009. Effect of ambient temperature, humidity, month of insemination and semen (fresh or frozen) on reproductive performance of Holstein cows treated with rbST in northern Mexico. MS Thesis. Univ. Aut. Agric. Antonio Narro, Torreon, Mexico.

Silanikove, N., F. Shapiro, and D. Shinder. 2009. Acute heat stress brings down milk secretion in dairy cows by up-regulating the activity of the milk-borne negative feedback regulatory system. BMC Physiol. 9:13

Sorensen, M. T., J. V. Norgaard, P. K. Theil, M. Vestergaard, and K. Sejrsen. 2006. Cell turnover and activity in mammary tissue during lactation and the dry period in dairy cows. J. Dairy Sci. 89:4632-4639

St. Pierre, N. R., B. Cobanov, and G. Schnitkey. 2003. Economic losses from heat stress by US livestock industries. J. Dairy Sci. 86(E Suppl.):E52-E77.

van Amburgh, M. E., D. M. Galton, D. E. Bauman, and R. E. Everett. 1997. Management and economics of extended calving intervals with use of bovine somatotropin. Livest. Prod. Sci. 50:15-28.

Wathes, D. C., Z. Cheng, N. Bourne, V. J. Taylor, M. P. Coffey, and S Brotherstone. 2007. Differences between primiparous and multiparous dairy cows in the inter-relationships between metabolic traits, milk yield and body condition score in the periparturient period. Domest. Anim. Endocrinol. 33:203-225.

West, J. W. 1994. Interactions of energy and bovine somatotropin with heat stress. J. Dairy Sci. 77:2091-2102.

West, J. W., B. G. Mullinix, and J. K. Bernard. 2003. Effects of hot, humid weather on milk temperature, dry matter intake and milk yield in lactating dairy cows. J. Dairy Sci. 86:232-242. 